\title{
Brevundimonas viscosa sp. nov., isolated from saline soil
}

\author{
Correspondence \\ Jianli Zhang \\ zhangjianli@bit.edu.cn
}

\author{
Jiewei Wang, ${ }^{1}$ Jianli Zhang, ${ }^{1}$ Kai Ding, ${ }^{1}$ Yuhua $X{ }^{2}{ }^{2}$ and Huancheng Pang ${ }^{3}$ \\ ${ }^{1}$ School of Life Science, Beijing Institute of Technology, Beijing 100081, PR China \\ ${ }^{2}$ China General Microbiological Culture Collection Center, Institute of Microbiology, \\ Chinese Academy of Sciences, Beijing 100101, PR China \\ ${ }^{3}$ Institute of Agri-resources and Regional Planning, CAAS, Beijing 100081, PR China
}

A Gram-negative, rod-shaped bacterial strain, designated $\mathrm{F}^{\top}$, was isolated from a saline soil sample in China and studied by using a polyphasic taxonomic approach. Phylogenetic analysis based on 16S rRNA gene sequences indicated that strain $\mathrm{F}^{\top}$ was affiliated with the genus Brevundimonas, with Brevundimonas kwangchunensis $\mathrm{KSL}-102^{\top}$ (98.4\% similarity) and Brevundimonas alba DSM $4736^{\top}(98.2 \%)$ as its closest relatives. Strain $\mathrm{F}^{\top}{ }^{\top}$ contained ubiquinone-10 (Q-10) as the predominant ubiquinone and $\mathrm{C}_{18: 1} \omega 7 c, \mathrm{C}_{17: 1} \omega 8 c$ and $\mathrm{C}_{16: 0}$ as the major fatty acids. The DNA G $+\mathrm{C}$ content of strain $\mathrm{F}^{\top}{ }^{\top}$ was $66.7 \mathrm{~mol} \%$. Levels of DNA-DNA relatedness between strain $\mathrm{F}^{\top}{ }^{\top}$ and the type strains of closely related Brevundimonas species were below $22 \%$. On the basis of phenotypic characteristics and genotypic distinctiveness, strain $\mathrm{F}^{\top}$ should be classified as representing a novel species of the genus Brevundimonas, for which the name Brevundimonas viscosa sp. nov. is proposed. The type strain is $\mathrm{F}^{\top}{ }^{\top}$ (=CGMCC $1.10683^{\top}=$ JCM $17426^{\top}$ ).
The genus Brevundimonas was proposed by Segers et al. (1994) based on the reclassification of two Pseudomonas species. Several Caulobacter species were subsequently transferred to the genus Brevundimonas (Abraham et al., 1999), and novel species of the genus were isolated from diverse habitats (Abraham et al., 2010; Choi et al., 2010; Estrela \& Abraham, 2010; Fritz et al., 2005; Kang et al., 2009; Li et al., 2004; Yoon et al., 2006a, b, 2007). At the time of writing, the genus comprises 21 recognized species (http:// www.bacterio.cict.fr/b/brevundimonas.html). Members of the genus Brevundimonas are Gram-negative and have relatively high DNA $\mathrm{G}+\mathrm{C}$ contents. Chemotaxonomically, members of the genus contain $\mathrm{C}_{18: 1} \omega 7 c$ and $\mathrm{C}_{16: 0}$ as the major fatty acids and ubiquinone-10 (Q-10) as the predominant ubiquinone.

In this study, we describe the morphological, biochemical and phylogenetic characteristics of a Brevundimonas-like strain, $\mathrm{F}^{\mathrm{T}}$. The organism was considered to be Brevundimonas-like on the basis of preliminary $16 \mathrm{~S}$ rRNA gene sequence comparisons. Accordingly, the aim of the present study was to elucidate the taxonomic position of strain $\mathrm{F} 3^{\mathrm{T}}$ by means of phenotypic, genetic and chemotaxonomic analyses.

\footnotetext{
The GenBank/EMBL/DDBJ accession number for the 16S rRNA gene sequence of strain $\mathrm{F}^{\top}{ }^{\top}$ is $\mathrm{HM} 777012$.

Two supplementary tables and two supplementary figures are available with the online version of this paper.
}

Strain $\mathrm{F}^{\mathrm{T}}$ was originally isolated from a saline soil sample collected from a coastal area of Hainan Province. It was isolated by the standard dilution-plating technique at $30{ }^{\circ} \mathrm{C}$ on nutrient agar (NA; Difco). To investigate its morphological, physiological and biochemical characteristics, strain $\mathrm{F} 3{ }^{\mathrm{T}}$ was routinely cultivated at $30{ }^{\circ} \mathrm{C}$ on trypticase soy agar (TSA; Difco). Cell morphology was observed under a Nikon light microscope with cells grown for 3 days at $30{ }^{\circ} \mathrm{C}$ on TSA. Motility of cells was studied on LuriaBertani swarming agar $(0.3 \%, \mathrm{w} / \mathrm{v})$, and the presence of flagella was examined by transmission electron microscopy of cells from exponentially growing cultures. Colony morphology was observed on TSA at $30{ }^{\circ} \mathrm{C}$ for 3 days. The Gram reaction was determined by using the bioMérieux Gram strain kit according to the manufacturer's instructions. The $\mathrm{pH}$ range for growth was determined in nutrient broth (NB; Difco) at $\mathrm{pH} 4.5-11.5$ (intervals of $0.5 \mathrm{pH}$ units) prior to sterilization by the addition of $\mathrm{HCl}$ or $\mathrm{Na}_{2} \mathrm{CO}_{3}$ (below $\mathrm{pH}$ 10.5) and $\mathrm{KOH}$ (above $\mathrm{pH}$ 10.5). Growth at $4,10,15,20,25,30,37$ and $40{ }^{\circ} \mathrm{C}$ was examined on TSA. Tolerance to $\mathrm{NaCl}$ was studied in trypticase soy broth (TSB; Difco) supplemented with 0-10\% (w/v) $\mathrm{NaCl}$. Growth under anaerobic conditions was determined after incubation in an anaerobic chamber on TSA and on TSA supplemented with nitrate, both of which had been preppared anaerobically by using a nitrogen atmosphere. Catalase and oxidase activities, and hydrolysis of casein, gelatin, hypoxanthine, starch, Tweens 20, 40, 60 and 80, tyrosine, urea and xanthine were determined as described 
by Cowan \& Steel (1965). Hydrolysis of aesculin and nitrate reduction were studied as described by Lányí (1987). Assimilation of various substrates was determined by using the Biolog GN2 MicroPlate assay as recommended by the manufacturer. Susceptibility to antibiotics was tested by placing antibiotic-impregnated discs on TSA plates that were seeded with suspensions of the test strain. The following antibiotics were used: polymyxin B (100 U), streptomycin $(50 \mu \mathrm{g})$, penicillin $\mathrm{G}(20 \mathrm{U})$, chloramphenicol $(100 \mu \mathrm{g})$, ampicillin $(10 \mu \mathrm{g})$, cephalothin $(30 \mu \mathrm{g})$, gentamicin $(30 \mu \mathrm{g})$, novobiocin $(5 \mu \mathrm{g})$, tetracycline $(30 \mu \mathrm{g})$, kanamycin $(30 \mu \mathrm{g})$, lincomycin $(15 \mu \mathrm{g})$ and oleandomycin $(15 \mu \mathrm{g})$. Enzyme activities and other physiological and biochemical properties were tested by using the API ZYM and API 20E systems (bioMérieux). Physiological and biochemical characteristics and the morphology of strain $\mathrm{F}^{\mathrm{T}}$ are shown in Table 1 and in Table S1 and Fig. S1

Table 1. Differential phenotypic characteristics between strain $\mathrm{F}^{\top}$ and the type strains of phylogenetically related species of the genus Brevundimonas

Strains: $1, \mathrm{~F}^{\mathrm{T}} ; 2$, B. aveniformis $\mathrm{EMB} 102^{\mathrm{T}} ; 3$, B. diminuta LMG $2089^{\mathrm{T}}$ (data from Ryu et al., 2007); 4, B. kwangchunensis KSL-102 ${ }^{\mathrm{T}}$. Data were taken from this study unless indicated otherwise. ND, Not determined; $w$, weakly positive. All strains were positive for oxidase and catalase and negative for arginine dihydrolase, $\beta$-galactosidase and hydrolysis of starch.

\begin{tabular}{|c|c|c|c|c|}
\hline Characteristic & 1 & 2 & 3 & 4 \\
\hline Urease & - & + & - & - \\
\hline Nitrate reduction & + & - & - & - \\
\hline \multicolumn{5}{|l|}{ Hydrolysis of: } \\
\hline Gelatin & + & + & - & - \\
\hline Tween 40 & + & - & + & - \\
\hline Tween 80 & + & - & - & - \\
\hline \multicolumn{5}{|l|}{ Utilization of: } \\
\hline Cellobiose & - & - & - & + \\
\hline D-Fructose & - & - & - & + \\
\hline D-Glucose & + & - & - & + \\
\hline Maltose & - & - & - & + \\
\hline D-Mannose & - & - & - & + \\
\hline Sucrose & - & - & - & + \\
\hline Trehalose & - & - & - & + \\
\hline Turanose & - & - & - & + \\
\hline Acetic acid & - & - & + & + \\
\hline Lactic acid & - & - & - & + \\
\hline Succinic acid & - & $\mathrm{w}$ & + & + \\
\hline D-Alanine & - & $\mathrm{w}$ & + & + \\
\hline L-Alanine & - & + & + & + \\
\hline L-Aspartic acid & - & + & + & + \\
\hline L-Leucine & - & - & + & - \\
\hline L-Serine & - & + & + & + \\
\hline Glucose 1-phosphate & - & - & + & + \\
\hline Glucose 6-phosphate & - & - & + & + \\
\hline DNA G $+C$ content $(\mathrm{mol} \%)$ & 66.7 & 64.1 & $66.0-68.0$ & 68.7 \\
\hline
\end{tabular}

available in IJSEM Online. Additional characteristics are given in the species description below.

Cell biomass for DNA extraction was obtained after cultivation in TSB at $30^{\circ} \mathrm{C}$. Chromosomal DNA was isolated and purified according to the method described by Yoon et al. (1996), with the exception that RNase T1 was used in combination with RNase A to minimize contamination with RNA. The $16 \mathrm{~S}$ rRNA gene was amplified by PCR by using two universal primers as described by Yoon et al. (1998). Sequencing of the amplified 16S rRNA gene was performed as described by Yoon et al. (2003). The EzTaxon server (http://www.eztaxon.org/; Chun et al., 2007) was used for determining the closest known relatives of strain $\mathrm{F}^{\mathrm{T}}$ and calculating levels of $16 \mathrm{~S}$ rRNA gene sequence similarity. The $16 \mathrm{~S}$ rRNA gene sequences of strain $\mathrm{F}^{\mathrm{T}}$ and related taxa (obtained from the NCBI database) were aligned by using the CLUSTAL $\mathrm{x} \quad 1.8$ program (Thompson et al., 1997). Phylogenetic trees were constructed with the neighbour-joining (Saitou \& Nei, 1987), maximum-parsimony (Kluge \& Farris, 1969) and maximum-likelihood methods using the MEGA4 program (Tamura et al., 2007), with bootstrap values based on 1000 replications. The phylogenetic tree constructed on the basis of $16 \mathrm{~S}$ rRNA gene sequences indicated that strain $\mathrm{F}^{\mathrm{T}}$ was most closely affiliated to the genus Brevundimonas. In the neighbour-joining phylogenetic tree, strain $\mathrm{F}^{\mathrm{T}}$ joined the cluster comprising Brevundimonas kwangchunensis KSL- $102^{\mathrm{T}}$ and Brevundimonas aveniformis $\mathrm{EMB102}{ }^{\mathrm{T}}$ (Fig. 1). The topologies of the phylogenetic trees constructed with the maximum-parsimony and maximum-likelihood (Fig. 1) algorithms also supported the notion that the isolate belongs to the genus Brevundimonas. Strain $\mathrm{F}^{\mathrm{T}}$ shared 98.4-95.5\% 16S rRNA gene sequence similarity with members of the genus Brevundimonas, and showed highest similarity to B. kwangchunensis KSL- $102^{\mathrm{T}}$ (98.4\%), Brevundimonas alba DSM $4736^{\mathrm{T}}(98.2 \%)$, Brevundimonas vesicularis ATCC $11426^{\mathrm{T}}$ (97.9\%), Brevundimonas lenta DS- $18^{\mathrm{T}}$ (97.7\%), Brevundimonas aurantiaca CB- $\mathrm{R}^{\mathrm{T}}(97.7 \%)$, Brevundimonas nasdae $\mathrm{W} 1-2 \mathrm{~B}^{\mathrm{T}}(97.7 \%)$, Brevundimonas intermedia DSM $4732^{\mathrm{T}}$ (97.6\%), Brevundimonas basaltis $\mathrm{J} 22^{\mathrm{T}}$ (97.5\%), B. aveniformis $\mathrm{EMB}^{2} 2^{\mathrm{T}}$ (97.1\%), Brevundimonas mediterranea V4.BO.10 $0^{\mathrm{T}}(97.1 \%)$ and Brevundimonas poindexterae $\mathrm{FWC40} 0^{\mathrm{T}}(97.0 \%)$. Levels of $16 \mathrm{~S}$ rRNA gene sequence similarity to the type strains of species of other genera included in the phylogenetic analysis were less than $95.6 \%$ (Fig. 1).

Cell biomass for isoprenoid quinone analysis was obtained after cultivation in TSB at $30{ }^{\circ} \mathrm{C}$. Isoprenoid quinones were extracted according to the method of Komagata \& Suzuki (1987) and were analysed by using reversed-phase HPLC and a YMC ODS-A $(250 \times 4.6 \mathrm{~mm})$ column. For cellular fatty acid analysis, cell mass of strain $\mathrm{F}^{\mathrm{T}}$ was harvested from TSA plates after incubation for 3 days at $30{ }^{\circ} \mathrm{C}$. The fatty acids were extracted and fatty acid methyl esters were prepared according to the standard protocol of the MIDI/ Hewlett Packard Microbial Identification System (Sasser, 1990); the database used was TSBA40. The DNA G +C content was determined according to the method of 


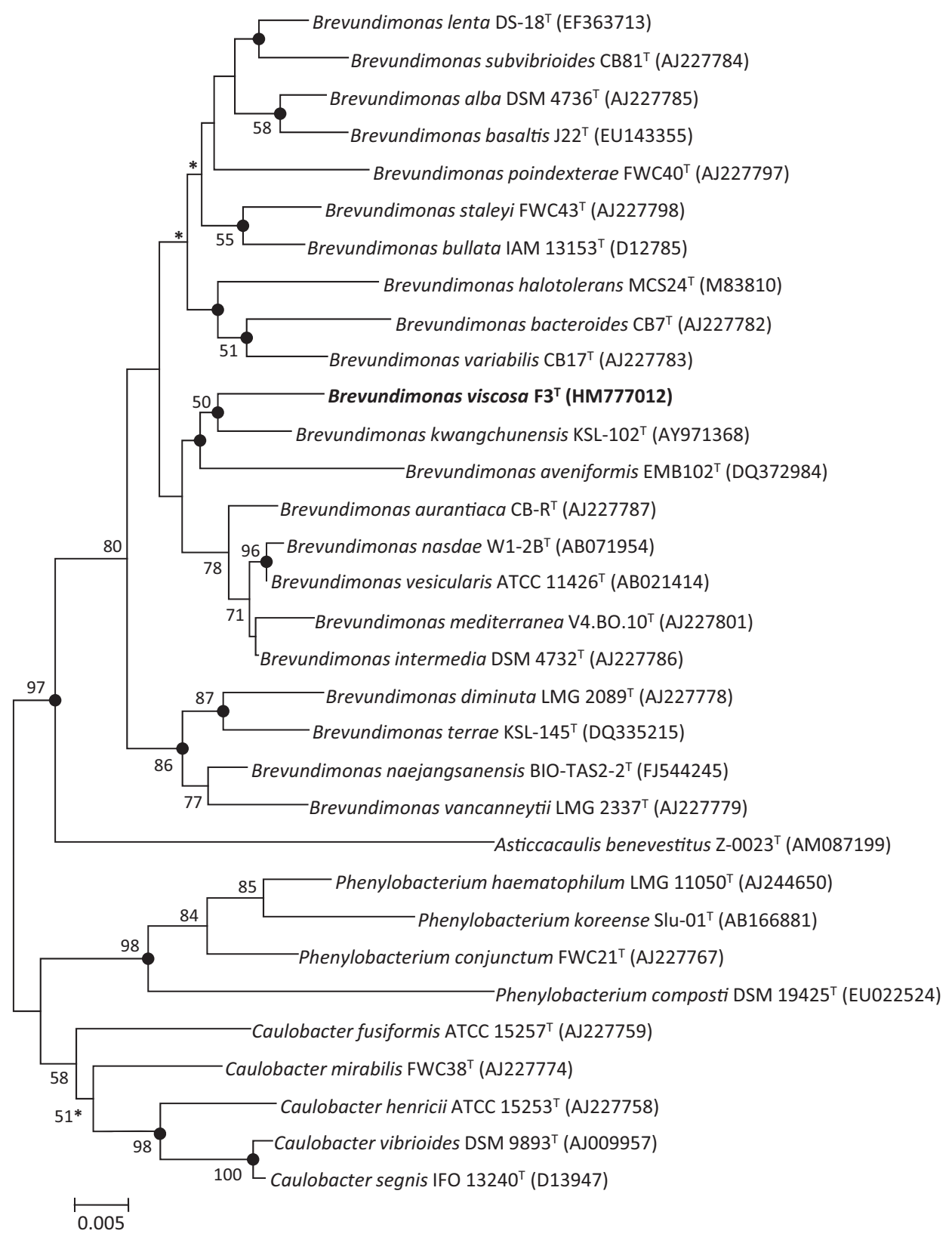

Fig. 1. Neighbour-joining phylogenetic tree based on $16 \mathrm{~S}$ rRNA gene sequences, showing the positions of strain $F 3^{\top}$, Brevundimonas species and some other related taxa. Filled circles and asterisks indicate that the corresponding branches were recovered in the neighbour-joining, maximum-parsimony and maximum-likelihood trees, and both neighbour-joining and maximum-parsimony trees, respectively. Bootstrap values (expressed as percentages of 1000 replications) $\geqslant 50 \%$ are shown at branch points. GenBank accession numbers are given in parentheses. Bar, 0.005 substitutions per nucleotide position.

Tamaoka \& Komagata (1984), with the modification that DNA was hydrolysed and the resultant nucleotides were analysed by reversed-phase HPLC. Chemotaxonomic properties confirmed the phylogenetic affiliation of strain $\mathrm{F}^{\mathrm{T}}{ }^{\mathrm{T}}$ to the genus Brevundimonas. The predominant isoprenoid quinone detected in strain $\mathrm{F}^{\mathrm{T}}$ was $\mathrm{Q}-10$. The major fatty acids ( $>10 \%$ of the total) were $\mathrm{C}_{18: 1} \omega 7 c(39.3 \%), \mathrm{C}_{17: 1} \omega 8 c$ $(14.8 \%)$ and $\mathrm{C}_{16: 0}(11.5 \%)$. This fatty acid profile was similar to those of recognized Brevundimonas species, although there were differences in the proportions of some components between the taxa (Table S2). The DNA G+C content of strain $\mathrm{F}^{\mathrm{T}}{ }^{\mathrm{T}}$ was $66.7 \mathrm{~mol} \%$.

For polar lipid analyses, strain $\mathrm{F}^{\mathrm{T}}$ was grown for 3 days in TSB at $30{ }^{\circ} \mathrm{C}$. Polar lipids extracted according to the method of Minnikin et al. (1979) were identified by 
two-dimensional TLC as described by Collins \& Jones (1980). The polar lipid profile comprised phosphatidylglycerol, diphosphatidylglycerol, two unknown glycolipids and one unknown phospholipid (Fig. S2).

DNA-DNA hybridization was performed fluorometrically according to the method of Ezaki et al. (1989) by using photobiotin-labelled DNA probes and microdilution wells. Hybridization was performed with five replications for each sample. The highest and lowest values obtained in each sample were excluded and the means of the remaining three values were quoted as DNA-DNA relatedness values. DNA-DNA hybridization experiments were carried out to evaluate the genomic DNA relatedness between strain $\mathrm{F}^{\mathrm{T}}$ and its most closely related Brevundimonas species. Strain $\mathrm{F}^{\mathrm{T}}$ exhibited levels of DNA-DNA relatedness of less than $22 \%$ to the type strains of $B$. kwangchunensis $(21.7 \%), B$. alba $(20.9 \%)$, B. vesicularis (18.6\%), B. lenta (17.5\%), B. aurantiaca $(15.9 \%)$, B. nasdae $(16.2 \%)$, B. intermedia (13.9\%), B. basaltis (12.3\%), B. aveniformis (11.1\%), B. mediterranea $(9.7 \%)$ and $B$. poindexterae $(8.6 \%)$. These values were significantly lower than the threshold of $70 \%$ that is commonly accepted for the definition of bacterial species (Wayne et al., 1987).

The major cellular fatty acids of strain $\mathrm{F}^{\mathrm{T}}$ were $\mathrm{C}_{18: 1} \omega 7 c$ and $\mathrm{C}_{16: 0}$, as with recognized Brevundimonas species, in particular Brevundimonas diminuta, the type species of the genus. The DNA G $+\mathrm{C}$ content of strain $\mathrm{F}^{\mathrm{T}}$ was $66.7 \mathrm{~mol} \%$, consistent with that of $B$. diminuta strains, which ranged from 66.0 to $68.0 \mathrm{~mol} \%$. Phylogenetically, strain $\mathrm{F}^{\mathrm{T}}$ formed a distinct clade within the genus Brevundimonas and clustered with $B$. kwangchunensis KSL-102 ${ }^{\mathrm{T}}$ and B. aveniformis $\mathrm{EMB} 102^{\mathrm{T}}$. In addition, it was closely related to B. kwangchunensis KSL-102 ${ }^{\mathrm{T}}$ based on 16S rRNA gene sequences ( $98.4 \%$ similarity). Therefore, strain $\mathrm{F}^{\mathrm{T}}{ }^{\mathrm{T}}$ should be assigned to the genus Brevundimonas. However, levels of DNA-DNA relatedness between strain $\mathrm{F}^{\mathrm{T}}$ and its closest relatives in the genus Brevundimonas were less than $22 \%$. Phylogenetic distinctiveness together with genetic data and differential phenotypic properties were sufficient to allocate strain $\mathrm{F}^{\mathrm{T}}$ to a species that is separate from recognized Brevundimonas species. On the basis of the data presented, strain $\mathrm{F}^{\mathrm{T}}$ is therefore considered to represent a novel species of the genus Brevundimonas, for which the name Brevundimonas viscosa sp. nov. is proposed.

\section{Description of Brevundimonas viscosa sp. nov.}

Brevundimonas viscosa (vis.co'sa. L. fem. adj. viscosa sticky).

Cells are Gram-negative, aerobic rods $(0.4-0.6 \times 0.9-2.5 \mu \mathrm{m})$. Motile by means of a single polar flagellum. Colonies on TSA are circular, smooth, slightly convex, white and $1-2 \mathrm{~mm}$ in diameter after 3 days of incubation at $30{ }^{\circ} \mathrm{C}$. Grows at 10 $36{ }^{\circ} \mathrm{C}$ (optimum $28-30{ }^{\circ} \mathrm{C}$ ), with $0-3 \% \quad(w / v) \quad \mathrm{NaCl}$ (optimum 0\%) and at pH 5.5-11.0 (optimum pH 7.0-8.0). Anaerobic growth does not occur on TSA or on TSA supplemented with nitrate. Hydrolyses casein, aesculin, tyrosine and Tweens 20 and 40, weakly hydrolyses Tween
60, but does not hydrolyse urea, hypoxanthine or xanthine. $\mathrm{H}_{2} \mathrm{~S}$ and indole are not produced. Lysine decarboxylase, ornithine decarboxylase and tryptophan deaminase are absent. Positive for activity of alkaline phosphatase, esterase (C4), esterase lipase (C8), leucine arylamidase, valine arylamidase, trypsin, acid phosphatase, naphthol-AS-BI-phosphohydrolase and $\alpha$-glucosidase. Negative for activity of lipase (C14), cystine arylamidase, $\alpha$-chymotrypsin, $\alpha$-galactosidase, $\beta$ glucuronidase, $\beta$-glucosidase, $N$-acetyl- $\beta$-glucosaminidase, $\alpha$-mannosidase and $\alpha$-fucosidase. Sensitive to chloramphenicol, cephalothin, novobiocin, tetracycline, kanamycin, polymyxin $\mathrm{B}$, ampicillin and gentamicin. The predominant ubiquinone is Q-10. Major fatty acids are $\mathrm{C}_{16: 0}, \mathrm{C}_{17: 1} \omega 8 c$ and $\mathrm{C}_{18: 1} \omega 7 \mathrm{c}$. The polar lipid profile comprises phosphatidylglycerol, diphosphatidylglycerol, two unknown glycolipids and one unknown phospholipid. The DNA G $+\mathrm{C}$ content of the type strain is $66.7 \mathrm{~mol} \%$. Other phenotypic characteristics are given in Tables 1 and $\mathrm{S} 1$.

The type strain, $\mathrm{F}^{\mathrm{T}}\left(=\mathrm{CGMCC} 1.10683^{\mathrm{T}}=\mathrm{JCM} 17426^{\mathrm{T}}\right)$, was isolated from saline soil in China.

\section{Acknowledgements}

This research was supported by the National Natural Science Foundation of China (NSFC; grant numbers 31070002, 30970009), by the Special Fund for Public Welfare Industrial (Agriculture) Research of China (grant number 200903001) and by the Basic Research Foundation of Beijing Institute of Technology (grant number 20091642006). We are grateful to Dr Yafang Tan for carrying out the quantitative fatty acid analysis on strain $\mathrm{F}^{\mathrm{T}}$.

\section{References}

Abraham, W.-R., Strömpl, C., Meyer, H., Lindholst, S., Moore, E. R. B., Christ, R., Vancanneyt, M., Tindall, B. J., Bennasar, A. \& other authors (1999). Phylogeny and polyphasic taxonomy of Caulobacter species. Proposal of Maricaulis gen. nov. with Maricaulis maris (Poindexter) comb. nov. as the type species, and emended description of the genera Brevundimonas and Caulobacter. Int J Syst Bacteriol 49, 1053-1073.

Abraham, W.-R., Estrela, A. B., Nikitin, D. I., Smit, J. \& Vancanneyt, M. (2010). Brevundimonas halotolerans sp. nov., Brevundimonas poindexterae sp. nov. and Brevundimonas staleyi sp. nov., prosthecate bacteria from aquatic habitats. Int J Syst Evol Microbiol 60, 1837-1843.

Choi, J. H., Kim, M.-S., Roh, S. W. \& Bae, J.-W. (2010). Brevundimonas basaltis sp. nov., isolated from black sand. Int J Syst Evol Microbiol 60, 1488-1492.

Chun, J., Lee, J. H., Jung, Y., Kim, M., Kim, S., Kim, B. K. \& Lim, Y. W. (2007). EzTaxon: a web-based tool for the identification of prokaryotes based on $16 \mathrm{~S}$ ribosomal RNA gene sequences. Int J Syst Evol Microbiol 57, 2259-2261.

Collins, M. D. \& Jones, D. (1980). Lipids in the classification and identification of coryneform bacteria containing peptidoglycans based on 2,4-diaminobutyric acid. J Appl Bacteriol 48, 459-470.

Cowan, S. T. \& Steel, K. J. (1965). Manual for the Identification of Medical Bacteria. London: Cambridge University Press.

Estrela, A. B. \& Abraham, W.-R. (2010). Brevundimonas vancanneytii sp. nov., isolated from blood of a patient with endocarditis. Int J Syst Evol Microbiol 60, 2129-2134. 
Ezaki, T., Hashimoto, Y. \& Yabuuchi, E. (1989). Fluorometric deoxyribonucleic acid-deoxyribonucleic acid hybridization in microdilution wells as an alternative to membrane filter hybridization in which radioisotopes are used to determine genetic relatedness among bacterial strains. Int J Syst Bacteriol 39, 224-229.

Fritz, I., Strömpl, C., Nikitin, D. I., Lysenko, A. M. \& Abraham, W.-R. (2005). Brevundimonas mediterranea sp. nov., a non-stalked species from the Mediterranean Sea. Int J Syst Evol Microbiol 55, 479-486.

Kang, S.-J., Choi, N.-S., Choi, J. H., Lee, J.-S., Yoon, J.-H. \& Song, J. J. (2009). Brevundimonas naejangsanensis sp. nov., a proteolytic bacterium isolated from soil, and reclassification of Mycoplana bullata into the genus Brevundimonas as Brevundimonas bullata comb. nov. Int J Syst Evol Microbiol 59, 3155-3160.

Kluge, A. G. \& Farris, F. S. (1969). Quantitative phyletics and the evolution of anurans. Syst Zool 18, 1-32.

Komagata, K. \& Suzuki, K. (1987). Lipids and cell-wall analysis in bacterial systematics. Methods Microbiol 19, 161-207.

Lányí, B. (1987). Classical and rapid identification methods for medically important bacteria. Methods Microbiol 19, 1-67.

Li, Y., Kawamura, Y., Fujiwara, N., Naka, T., Liu, H., Huang, X., Kobayashi, K. \& Ezaki, T. (2004). Sphingomonas yabuuchiae sp. nov. and Brevundimonas nasdae sp. nov., isolated from the Russian space laboratory Mir. Int J Syst Evol Microbiol 54, 819-825.

Minnikin, D. E., Collins, M. D. \& Goodfellow, M. (1979). Fatty acid and polar lipid composition in the classification of Cellulomonas, Oerskovia and related taxa. J Appl Bacteriol 47, 87-95.

Ryu, S. H., Park, M., Lee, J. R., Yun, P.-Y. \& Jeon, C. O. (2007). Brevundimonas aveniformis sp. nov., a stalked species isolated from activated sludge. Int J Syst Evol Microbiol 57, 1561-1565.

Saitou, N. \& Nei, M. (1987). The neighbor-joining method: a new method for reconstructing phylogenetic trees. Mol Biol Evol 4, 406425.

Sasser, M. (1990). Identification of bacteria by gas chromatography of cellular fatty acids, MIDI Technical Note 101. Newark, DE: MIDI Inc.

Segers, P., Vancanneyt, M., Pot, B., Torck, U., Hoste, B., Dewettinck, D., Falsen, E., Kersters, K. \& De Vos, P. (1994). Classification of Pseudomonas diminuta Leifson and Hugh 1954 and Pseudomonas vesicularis Büsing, Döll, and Freytag 1953 in Brevundimonas gen. nov. as Brevundimonas diminuta comb. nov. and Brevundimonas vesicularis comb. nov., respectively. Int J Syst Bacteriol 44, 499-510.

Tamaoka, J. \& Komagata, K. (1984). Determination of DNA base composition by reverse-phase high-performance liquid chromatography. FEMS Microbiol Lett 25, 125-128.

Tamura, K., Dudley, J., Nei, M. \& Kumar, S. (2007). MEGA4: molecular evolutionary genetics analysis (MEGA) software version 4.0. Mol Biol Evol 24, 1596-1599.

Thompson, J. D., Gibson, T. J., Plewniak, F., Jeanmougin, F. \& Higgins, D. G. (1997). The CLUSTAL_X windows interface: flexible strategies for multiple sequence alignment aided by quality analysis tools. Nucleic Acids Res 25, 4876-4882.

Wayne, L. G., Brenner, D. J., Colwell, R. R., Grimont, P. A. D., Kandler, O., Krichevsky, M. I., Moore, L. H., Moore, W. E. C., Murray, R. G. E. \& other authors (1987). International Committee on Systematic Bacteriology. Report of the ad hoc committee on reconciliation of approaches to bacterial systematics. Int J Syst Bacteriol 37, 463-464.

Yoon, J.-H., Kim, H., Kim, S.-B., Kim, H.-J., Kim, W. Y., Lee, S. T., Goodfellow, M. \& Park, Y.-H. (1996). Identification of Saccharomonospora strains by the use of genomic DNA fragments and rRNA gene probes. Int J Syst Bacteriol 46, 502-505.

Yoon, J.-H., Lee, S. T. \& Park, Y.-H. (1998). Inter- and intraspecific phylogenetic analysis of the genus Nocardioides and related taxa based on 16S rDNA sequences. Int J Syst Bacteriol 48, 187-194.

Yoon, J.-H., Kang, K. H. \& Park, Y.-H. (2003). Psychrobacter jeotgali sp. nov., isolated from jeotgal, a traditional Korean fermented seafood. Int J Syst Evol Microbiol 53, 449-454.

Yoon, J.-H., Kang, S.-J., Oh, H. W., Lee, J.-S. \& Oh, T.-K. (2006a). Brevundimonas kwangchunensis sp. nov., isolated from an alkaline soil in Korea. Int J Syst Evol Microbiol 56, 613-617.

Yoon, J.-H., Kang, S.-J., Lee, J.-S. \& Oh, T.-K. (2006b). Brevundimonas terrae sp. nov., isolated from an alkaline soil in Korea. Int J Syst Evol Microbiol 56, 2915-2919.

Yoon, J.-H., Kang, S.-J., Lee, J.-S., Oh, H. W. \& Oh, T.-K. (2007). Brevundimonas lenta sp. nov., isolated from soil. Int J Syst Evol Microbiol 57, 2236-2240. 